SHOCK THERAPY 



\section{SHOCK THERAPY}

A History of

Electroconvulsive Treatment in Mental Illness

\section{EDWARD SHORTER}

DAVID HEALY

Rutgers University Press

NEW BRUNSWICK, NEW JERSEY, AND LONDON 
Library of Congress Cataloging-in-Publication Data

Shorter, Edward.

Shock therapy : a history of electroconvulsive treatment in mental illness / Edward Shorter, David Healy.

p. ; cm.

Includes bibliographical references and index.

ISBN 978-0-8135-4169-3 (hardcover : alk. paper)

1. Electroconvulsive therapy-History. I. Healy, David, MRC Psych. II. Title.

[DNLM: 1. Electroconvulsive Therapy-history. 2. History, 2oth Century. 3. Mental Disorders-therapy. WM 11.1 S559s 2007]

RC485.S56 2007

$616.89^{\prime} 122-\mathrm{dc} 22$

2006039516

A British Cataloging-in-Publication record for this book is available from the British Library.

Copyright (c) 2007 by Edward Shorter and David Healy

All rights reserved

No part of this book may be reproduced or utilized in any form or by any means, electronic or mechanical, or by any information storage and retrieval system, without written permission from the publisher. Please contact Rutgers University Press, 100 Joyce Kilmer Avenue, Piscataway, NJ 08854-8099. The only exception to this prohibition is "fair use" as defined by U.S. copyright law.

Visit our Web site: http://rutgerspress.rutgers.edu

Manufactured in the United States of America 
It was a small band of European émigrés-Italians, Germans and Austrians, and Jews for the most part—who saw the merits in electroconvulsive therapy and sustained its use despite professional antipathy and ostracism, and public and governmental attacks. They are unacknowledged heroes in the twentieth-century history of psychiatry. This book is in their memory. 
